\title{
Screening of Some Sudanese Sorghum Cultivars for Better Phosphorus Use Efficiency
}

\author{
Mona Habib Ali*, Yassin Mohmed Ibrahim Dagash, Sami Ali Mohamed Hamid \\ Department of Crops Science (Agronomy), Faculty of Agricultural Studies, Sudan University of Science and Technology, Sudan
}

Copyright $\mathrm{C} 2019$ by authors, all rights reserved. Authors agree that this article remains permanently open access under the terms of the Creative Commons Attribution License 4.0 International License

\begin{abstract}
The experiment was conducted during summer seasons (2014), in Demonstration Farm of the Collage of Agricultural Studies at Shambat, Sudan University of Science and Technology, in order to study the effect of phosphorus fertilizer on growth and productivity of five cultivars of sorghum (Sorghum bicolor L. (Moench)., and also to evaluate phosphorus use efficiency. The experiment was arranged in split plot trial with addition of phosphorus as main plot (with and without) and five sorghum cultivars (Butana, Tabat, Arfagadamak, Wad Ahmed, Tetron) as the sub-plot with four replications. Plant height $(\mathrm{cm})$, number Leaves, Leaf area $\left(\mathrm{cm}^{2}\right)$, Stem diameter plant fresh weight $(\mathrm{kg})$, plant dry weight $(\mathrm{kg})$, length of panicle $(\mathrm{cm})$, weight of seeds panicle $(\mathrm{g})$, weight of 100 seeds $(\mathrm{g})$, number of panicle, yied/t/ha and phosphorus use efficiency, were measured. The results revealed that phosphorus affected yield and growth characters. Arfagadamak cultivar revealed the best use, therefore the highest productivity $(12.75 \mathrm{tan} / \mathrm{h})$, and Wadahmed showed the lowest use of phosphorus and therefore the lowest productivity $(9.45 \tan / \mathrm{h})$.
\end{abstract}

Keywords Phosphorus Use Efficiency, Screening, Productivity

\section{Introduction}

Sorghum (Sorghum bicolor (L.) Moench $2 \mathrm{n}=20$ ) is the fourth most important cereal crop following wheat, rice and maize. It is a food staple for more than 500 million people in the semi-arid tropics of Africa and Asia and more than $80 \%$ of the world area of production is confined to these two continents. In sub-Saharan Africa, over 100 million people depend on sorghum as staple food (GIZ, 2014). It is primarily a crop of resource-poor small-scale farmers and is grown predominantly in low-rainfall, arid to semi-arid environments. The crop is typically produced under adverse conditions such as low input use and marginal lands. It is well adapted to a wide range of precipitation and temperature levels and is produced from sea level to above $2000 \mathrm{~m}$. Due to its drought tolerance and adaptation attributes, this crop is grown in Sudan where agricultural and environmental conditions are unfavorable for the production of other crops. All lines of evidence point to the north-east quadrant of Africa, mainly Ethiopia, as the center of domestication of sorghum. Therefore, the greatest genetic diversity for both cultivated and wild forms of sorghum is found in Ethiopia and the surrounding eastern African countries. It is the second most important staple cereal crop after maize in the region and the first in Sudan, making a huge contribution to the domestic food supply chain and rural household incomes. Earlier data sources indicated that Sudan accounted for $21.4 \%$ of Africa's sorghum production, second to Nigeria, which produced $33.8 \%$ of the total harvest. And, Ethiopia accounted for $7.3 \%$, Uganda $2 \%$, and Kenya $0.6 \%$. Sudan, Ethiopia, Nigeria and Burkina Faso account for nearly $70 \%$ of Africa's production (Reda, 2014)

The crop is generally suited to hot and dry areas where it is difficult to grow other food grains. These are also areas subject to frequent drought. In many of these areas, sorghum is truly a dual-purpose crop; both grain and stover are highly valued outputs. In large parts of the developing world, Stover represents up to 50 percent of the total value of the crop, especially in drought years (Abdelrahman, 1998). Sorghum is widely produced in the Sudan by the traditional, semi-mechanized and large commercial farms. Technology is developed and supplied by the Agricultural Research Corporation and the universities, and the extension is responsible for the dissemination part. Up until recently, this process was informal and in-efficient but of late efforts are being made to formalize the linkages, and the research and extension have come to the extent of organizing common platforms to expedite the technology promotion process (Reda, 2014). The technology and input supply and distribution system is fairly well developed in the country and it is fully liberalized. There are a host of private companies with agents in the districts handling seed and input sales and direct delivery. Cooperatives are also involved in purchasing from companies and distributing to 
their member farmers. However, access to input credit is limited because it does not come on time and the process is time consuming. Sudan Agricultural Bank, Farmer commercial bank are involved in credit provision. Although, there is a big commercial company called Shekan with crop insurance provisions very few take benefit of the privilege because of lack of awareness, religious and other reasons.( Reda,2014)

The harvest is estimated to result in a national surplus of 0.98 million MT of sorghum. The government has lifted bans on exports to neighboring countries, and exports have begun to Ethiopia and Eritrea. However, formal exports have not resumed to South Sudan, given ongoing border tensions, though informal flows continue. Average sorghum prices in December were six percent lower than export parity prices, a factor that is likely to reduce competitiveness of Sudanese sorghum on international markets (Sudan Food Security Outlook, 2013). In most years, the Sudan has a surplus of sorghum and a balance of millet, but has a great wheat deficit. Sorghum is the staple food for most people living in the Sudan, except for the two northern states where wheat is the traditional staple. It is consumed in a number of ways, most notably as a flat bread or pancake known as "kisra" and as a pudding known as "acida". Large quantities of sorghum, particularly in the western and southern states are made into beer known as "marisa". The total population in Sudan is estimated at 30 million, consuming about 3.1 million tonnes of sorghum annually (2.7 million tonnes for human consumption and 400,000 tonnes for animal feed). This represents a daily human consumption rate of about $250 \mathrm{~g}$. of sorghum in one form or another (Mahgoub, 2014).

To increase grain yield and to improve the quality to meet the high demand of the human poultry food, proper cultural practices and land preparation, seed, rate, time of sowing irrigation and fertilization should be optimized. Phosphorus (P) is one of the most important nutrients (next only to nitrogen) limiting crop production in many regions of the world. To improve the Phosphorus nutrition of plants, the traditional approach is to apply large amounts of $\mathrm{P}$ fertilizers to soils. However, the use efficiency of applied Phosphorus is generally very low, ranging from $10 \%$ to $30 \%$ in the year (McLaughlin et al., 1991). Continuous application of Phosphorus fertilizers also increases the risk of Phosphorus loss from soil to water, causing toxic algal blooms in water bodies (Sharpley et al., 2000). Improving plant uptake of Phosphorus from soil is an important part of the management systems for low Phosphorus soils and the enhancement of use efficiency of Phosphorus fertilizers Genetic variations in Phosphorus uptake efficiencies have been widely reported in many crops, such as clover (Trolove et al., 1996) Sorghum bicolor is generally known to be heavy grains and exhaustive to available mineral nutrients in the soil, therefore fertilization is considered to be one of important cultural practices. Currently most of the farms are using urea and triple-super-phosphate as fertilizer sources of nitrogen and phosphorus, so as to increase the yield of sorghum grain. Therefore the main objective of this work is to study the response of five sorghum cultivars to phosphorus and to calculate phosphorus use efficiency

\section{Materials and Methods}

\subsection{Genetic Materials Used in the Study}

The genetic material used in this study was consisted of five cultivars of Sorghum (Sorghum bicolor L. Moench) obtained from Agricultural Research Corporation (ARC), Wad Madni.

Table 1. List of sorghum genotypes used in the study

\begin{tabular}{|l|l|lr|}
\hline $\begin{array}{l}\text { Entry } \\
\text { No. }\end{array}$ & Variety & Origin & \\
\hline 1 & Wed ahammed & $\begin{array}{l}\text { Plant Genetic Resource Unit } \\
\text { (ARC). }\end{array}$ \\
\hline 2 & Tetron & $\begin{array}{l}\text { CAS. SUSTECH, Released by } \\
\text { (ARC). CAS.SUSTECH, Released } \\
\text { by (ARC). }\end{array}$ \\
\hline 3 & Arfagadamk & $\begin{array}{l}\text { CAS.SUSTECH, Released by } \\
\text { (ARC). }\end{array}$ \\
\hline 4 & Botana & $\begin{array}{l}\text { CAS.SUSTECH, Released by } \\
\text { (ARC). }\end{array}$ \\
\hline 5 & Tabet & $\begin{array}{l}\text { Plant Genetic Resource Unit } \\
\text { (ARC). }\end{array}$ \\
\hline
\end{tabular}

ARC: Agricultural Research Corporation, Sudan. CAS.SUSTECH College of Agricultural Studies Sudan University of Science and Technology.

\subsection{Field Experiments}

The experiments were carried out at the Demonstration farm, College of Agricultural Studies, Sudan University of Science and Technology at Shambatis, located on longitude $32.35 " \mathrm{E}$ and latitude 15.31" $\mathrm{N}$, within the semi-desert region (Adam (2003). The soil of the site is loamy clay with $\mathrm{pH}, 8.2$ as described by Abdelgadir (2010) The experiments was laid out in split plot arrangement in a randomized complete block design (RCBD) with four replications. The main plot is addition of phosphorus or without addition of phosphorus while the sub-plot is the five sorghum cultivars. The field was disc ploughed, disc harrowed leveled and ridged up north-south, $70 \mathrm{~cm}$ apart. The land was divided into $2 \times 3.5 \mathrm{~m}^{2}$ plots, each composed of 4 ridges two meters long. Seed were sown in low than the top of the ridge with, $2.5 \mathrm{~cm}$ spacing between holes. Phosphorus fertilizer was applied to the experiment at sowing with a rate of $90 / \mathrm{gm} . / \mathrm{plot}$. The experiment comprised of 40 plots. Seed were planted by hand in 24/7/2013.Seed rate applied was $(6.12 \mathrm{~kg} / \mathrm{ha})$.All plots were irrigated at sowing (25/7/2013), Weed were controlled by hand weeding, the first weeding was done ten days after sowing (5/8/2013)and the second weeding at $20 / 8 / 2013$. 
Unless otherwise indicated, the following characters were taken for five plants at each plot randomly selected and tagged and from them data for the following growth and yield characters were measured

For available phosphorus, Olsen (1954) method was used using spectrophotometer modal (6305) and tissues phosphorus were determined using standard analytical method (Ryan 1996)

\subsection{Phosphorus Use Efficiency (PUA)}

In general four terms are used in relation to (PUE). These are: Agronomic Efficiency (AE), Recovery (RE) partial (PE) factor productivity of fertilizations (PFPF). The following expressions were used:

- $\quad \mathrm{AE}\left(\mathrm{Kg} /\right.$ grain $\mathrm{Kg} \mathrm{P}^{-1}$ applied $)=$

- $\quad \mathrm{RE}(\%$ of $\mathrm{P}$ taken by crops $)=$

- $\mathrm{PE}(\mathrm{Kg}$ grain. $\mathrm{Kg} \mathrm{P}$ taken UP by crop $)=$

- $\quad$ PFPF $\left(\mathrm{Kg}\right.$ grain-Kg $\mathrm{P}^{-1}$ applied $)=$

In the above expression, yf and yc are the yields( $\mathrm{Kg} / \mathrm{ha})$ in fertilizer and control (no fertilizer) plots, respectively PUF and PUC are the amounts of phosphorus taken UP by a crop in fertilized and control plots, receptivity and $\mathrm{Pa}$ refers to the amount applied ( $\mathrm{Kg} / \mathrm{ha})$.

$\mathrm{AE}$ is the same as crop response ratio, or productivity index used by (FAO.1989) and can be determined for a single nutrients $(\mathrm{N}, \mathrm{P}$ or $\mathrm{k})$ or for a combination of nutrients (N, P, K or NPK), or for a fertilizer. PPF can also be determined for a single or a combination of nutrient or for a fertilizer. PPF permits companion of fertilizer use efficiency in different countries or in different regions of a country. The term is useful in comparing the advantages of fertilizer use in experiment.

The collected data for growth and yield was subjected to analysis of variance for a randomized complete block design (RCBD).The means were separated using MSTAT-C.

\section{Results and Discussion}

\subsection{Growth Characters}

\subsubsection{Plant Height $(\mathrm{cm})$}

Statistical analysis revealed significant differences between phosphorus treatment and there was a high significant differences ---- among the five genotypes of sorghum (Table 2). However, the interaction between phosphorus and the five genotypes of sorghum were not significant. The taller plants were attained in plant which treated with phosphorus $(131.66 \mathrm{~cm})$ while the shortest were obtained at without phosphorus $(124.09 \mathrm{~cm})$.As shown in (Table 4) Titron gave significantly taller plants $(185.50 \mathrm{~cm})$ than the other four varieties. The interaction between phosphorus and the five genotypes of sorghum revealed that Titron with phosphorus and without phosphorus gave significant taller plants $(188.85 \mathrm{~cm})$ and (182.15) respectively than the other comparisons while Wadahmed without phosphorus gave significantly lower plant height $(99.97 \mathrm{~cm})$ as shown in Table (5).

Table 2. F- Values of different characters of Sorghum

\begin{tabular}{|c|c|c|c|c|c|c|c|c|c|c|c|}
\hline \multirow[b]{2}{*}{ SOURCE } & \multirow[b]{2}{*}{$\mathrm{DF}$} & \multicolumn{10}{|l|}{ F. value } \\
\hline & & $\begin{array}{l}\text { Plant } \\
\text { height } \\
(\mathrm{cm})\end{array}$ & $\begin{array}{l}\text { Number } \\
\text { of leaves }\end{array}$ & $\begin{array}{l}\text { Stem } \\
\text { diameter } \\
(\mathrm{cm})\end{array}$ & $\begin{array}{l}\text { Leaf } \\
\text { Area } \\
(\mathrm{cm} 2)\end{array}$ & $\begin{array}{l}\text { plant } \\
\text { fresh } \\
\text { weight } \\
(\mathrm{g})\end{array}$ & $\begin{array}{l}\text { Plant } \\
\text { dry } \\
\text { weight } \\
\text { (g) }\end{array}$ & $\begin{array}{l}\text { Length } \\
\text { of } \\
\text { panicle }\end{array}$ & $\begin{array}{l}\text { Weight } \\
\text { of seeds } \\
\text { /panicle }\end{array}$ & $\begin{array}{l}\text { Weight } \\
\text { of } 100 \\
\text { seeds }\end{array}$ & $\begin{array}{l}\text { Number } \\
\text { of } \\
\text { panicle }\end{array}$ \\
\hline REP & 3 & - & - & - & - & - & - & - & - & - & \\
\hline phosphorus & 1 & $9.79 *$ & $248.57 * *$ & $244.16^{* *}$ & $33.92 *$ & $13.15^{*}$ & $1.28 \mathrm{NS}$ & $10.05^{*}$ & $133.58 * *$ & $34.94 * *$ & $10.16^{*}$ \\
\hline ERROR a & 3 & - & - & - & - & - & - & - & - & - & - \\
\hline Cultivars & 4 & $123.11 * *$ & $3.76^{*}$ & $2.39 *$ & $51.27 * *$ & $4.52 * *$ & $0.86 \mathrm{Ns}$ & $2.83 * *$ & $1.06 \mathrm{Ns}$ & $0.92 \mathrm{Ns}$ & $2.82 *$ \\
\hline $\begin{array}{l}\text { A } \\
\text { TREAT*VAR }\end{array}$ & 4 & $0.37 \mathrm{Ns}$ & $1.12 \mathrm{Ns}$ & $0.26 \mathrm{Ns}$ & $0.17 \mathrm{Ns}$ & $\begin{array}{l}1.12 \\
\mathrm{Ns}\end{array}$ & $\begin{array}{l}1.72 \\
\mathrm{Ns}\end{array}$ & $\begin{array}{l}1.49 \\
\mathrm{Ns}\end{array}$ & $0.21 \mathrm{Ns}$ & $1.07 \mathrm{Ns}$ & $0.29 \mathrm{Ns}$ \\
\hline ERROR b & 24 & - & - & - & - & - & - & - & - & - & - \\
\hline TOTAL & 39 & - & - & - & - & - & - & - & - & - & - \\
\hline EMS & - & 80.79 & 0.95 & 0.49 & 32.59 & 0.01 & 0.16 & 0.26 & 9.67 & 2.85 & 21.06 \\
\hline $\mathrm{CV}$ & - & 35.34 & 8.27 & 6.21 & 4.10 & 24.35 & 32.88 & 16.75 & 13.88 & 8.25 & 8.67 \\
\hline $\mathrm{SE} \pm$ & - & 1.17 & 0.5 & 0.05 & 0.74 & 0,02 & 0.26 & 0.07 & 0.37 & 0.51 & 0.67 \\
\hline
\end{tabular}

$\mathrm{CV}=$ Coefficient of Variation. $\mathrm{SE}=$ Standard Error. 


\subsubsection{Number of Leaves/Plant}

The high significant differences were shown in phosphorus but there is a regular significant difference (0.05) among the five genotypes of sorghum (Table 2). However the interaction between phosphorus and the five genotypes of sorghum was not significant. The highest number of leaves was attained in plant which treated with phosphorus (12.345) while the lowest were obtained without phosphorus (11.220) (Table 3). As shown in (Table 4) Wadahmed gave significantly high number of leaves in plants (12.89) than the other four varieties. The interaction between phosphorus and the five genotypes of sorghum revealed that Wadahmed with phosphorus had significantly the highest number of leave in plants (13.33) than the other comparisons while Arfagadamk without phosphorus had the significantly the lowest number (10.65) as shown in Table (5). The correlation was positive except for the number of leaves which was negative $\left(-0.10^{\text {ns }}\right)$.

Table 3. Effect of Phosphorus on Different Parameters of Sorghum:

\begin{tabular}{|c|c|c|c|c|c|c|c|c|c|c|}
\hline $\begin{array}{c}\text { Parameter } \\
\text { Treat }\end{array}$ & $\begin{array}{c}\text { plant } \\
\text { height } \\
(\mathrm{cm})\end{array}$ & $\begin{array}{c}\text { Number } \\
\text { of leaves }\end{array}$ & $\begin{array}{c}\text { Stem } \\
\text { diameter } \\
(\mathrm{cm})\end{array}$ & $\begin{array}{c}\text { Leaf } \\
\text { Area } \\
(\mathrm{cm} 2)\end{array}$ & $\begin{array}{c}\text { Plant } \\
\text { fresh } \\
\text { weight } \\
(\mathrm{g})\end{array}$ & $\begin{array}{c}\text { Plant } \\
\text { dry } \\
\text { weight } \\
(\mathrm{g})\end{array}$ & $\begin{array}{c}\text { Length } \\
\text { of } \\
\text { panicle }\end{array}$ & $\begin{array}{c}\text { Weight } \\
\text { of seed } \\
\text { panicle }\end{array}$ & $\begin{array}{c}\text { Weight } \\
\text { of 100 } \\
\text { seeds }\end{array}$ & $\begin{array}{c}\text { Number } \\
\text { of panicle }\end{array}$ \\
\hline P+ & 131.66 & 12.34 & 11.99 & 142.17 & 0.50 & 0.40 & 21.63 & 25.50 & 3.42 & 54.50 \\
\hline P- & 124.09 & 11.22 & 10,69 & 136.02 & 0.47 & 0.36 & 19.32 & 2.76 & 19.29 & 51.40 \\
\hline Means & 127.87 & 11.78 & 11,34 & 13.09 & 0.53 & 0.36 & 20.47 & 22.39 & 3.09 & 52.95 \\
\hline LSD & 5.74 & 0.58 & 0.43 & 3.56 & 0.08 & 0.08 & 1,14 & 1.93 & 0.32 & 1.47 \\
\hline
\end{tabular}

$(\mathrm{p}+)$ : With phosphorus. (p-): Without phosphorus

Table 4. Effect of Cultivars on Different Parameter of Sorghum:

\begin{tabular}{|l|l|l|l|l|l|l|l|l|l|l|l|}
\hline $\begin{array}{l}\text { Parameter } \\
\text { Cultivar }\end{array}$ & $\begin{array}{l}\text { Yield } \\
\text { /T/ha }\end{array}$ & $\begin{array}{l}\text { plant } \\
\text { height } \\
(\mathrm{cm})\end{array}$ & $\begin{array}{l}\text { Number } \\
\text { of } \\
\text { leaves }\end{array}$ & $\begin{array}{l}\text { Stem } \\
\text { diameter } \\
(\mathrm{cm})\end{array}$ & $\begin{array}{l}\text { Leaf } \\
\text { Area } \\
\left(\mathrm{cm}^{2}\right)\end{array}$ & $\begin{array}{l}\text { Plant } \\
\text { fresh } \\
\text { weight } \\
(\mathrm{kg})\end{array}$ & $\begin{array}{l}\text { Plant } \\
\text { dry } \\
\text { weight } \\
(\mathrm{kg})\end{array}$ & $\begin{array}{l}\text { Length } \\
\text { of } \\
\text { panicle }\end{array}$ & $\begin{array}{l}\text { Weight } \\
\text { of } \\
\text { seeds } \\
\text { /panicle }\end{array}$ & $\begin{array}{l}\text { Weight } \\
\text { of } \\
\text { seeds }(\mathrm{g})\end{array}$ & $\begin{array}{l}\text { Number/ } \\
\text { panicle }\end{array}$ \\
\hline Titron & 9.17 & $185.50^{\mathrm{A}}$ & $11.65^{\mathrm{B}}$ & $11.32^{\mathrm{AB}}$ & $127.55^{\mathrm{D}}$ & $0.60^{\mathrm{A}}$ & $0.38^{\mathrm{A}}$ & $22.00^{\mathrm{A}}$ & $22.81^{\mathrm{A}}$ & $2.87^{\mathrm{A}}$ & $52.25^{\mathrm{B}}$ \\
\hline Butana & 9.30 & $138.00^{\mathrm{B}}$ & $11.15^{\mathrm{B}}$ & $11.90^{\mathrm{A}}$ & $128.90^{\mathrm{CD}}$ & $0.36^{\mathrm{B}}$ & $0.46^{\mathrm{A}}$ & $19.81^{\mathrm{B}}$ & $23.93^{\mathrm{A}}$ & $3.05^{\mathrm{A}}$ & $57.62^{\mathrm{A}}$ \\
\hline Arfagadamk & 10.10 & $107.04^{\mathrm{C}}$ & $11.82^{\mathrm{B}}$ & $11.16^{\mathrm{B}}$ & $142.93^{\mathrm{B}}$ & $0.57^{\mathrm{A}}$ & $0.37^{\mathrm{A}}$ & $19.50^{\mathrm{B}}$ & 21.53 & $3.06^{\mathrm{A}}$ & $50.500^{\mathrm{B}}$ \\
\hline Tabat & 8.75 & $107.04^{\mathrm{C}}$ & $11.40^{\mathrm{B}}$ & $11.46^{\mathrm{AB}}$ & $162.60^{\mathrm{B}}$ & $0.55^{\mathrm{A}}$ & $0.35^{\mathrm{A}}$ & $20.93^{\mathrm{B}}$ & $22.67^{\mathrm{A}}$ & $3.12^{\mathrm{A}}$ & $52.12^{\mathrm{B}}$ \\
\hline Wadahmed & 8.17 & $101.66^{\mathrm{C}}$ & $12.88^{\mathrm{A}}$ & $10.85^{\mathrm{B}}$ & $133.51^{\mathrm{c}}$ & $0.57^{\mathrm{A}}$ & $0.37^{\mathrm{A}}$ & $20.15^{\mathrm{B}}$ & $21.05^{\mathrm{B}}$ & $3.36^{\mathrm{A}}$ & $52.12^{\mathrm{B}}$ \\
\hline Means & 9.09 & 127.84 & 11.78 & 11.33 & 139.09 & 0.53 & 0.38 & 20.47 & 22.39 & $3.09^{\mathrm{A}}$ & 52.92 \\
\hline LSD & 0.5 & 9.07 & 0.94 & 0.68 & 5.63 & 0.13 & 0.12 & 1.81 & 3.06 & $0.51^{\mathrm{A}}$ & 4.55 \\
\hline
\end{tabular}

Means followed by the same letter each parameter are not significantly different at $5 \%$ Level according to LSD 
Table 5. Interaction between Phosphorus and Sorghum Cultivars for Different Parameters

\begin{tabular}{|c|c|c|c|c|c|c|c|c|c|c|c|}
\hline \multirow[b]{2}{*}{ Cultivars } & \multirow[b]{2}{*}{ phosphorus } & \multicolumn{10}{|c|}{ Characters measured } \\
\hline & & $\begin{array}{l}\text { Plant } \\
\text { height }(\mathrm{cm})\end{array}$ & $\begin{array}{l}\text { Leaf } \\
\text { number }\end{array}$ & $\begin{array}{l}\text { Stem } \\
\text { diameter }\end{array}$ & $\begin{array}{l}\text { Leaf area } \\
\left(\mathrm{cm}^{2}\right)\end{array}$ & $\begin{array}{l}\text { Plant } \\
\text { Fresh } \\
\text { Weight } \\
(\mathrm{kg}) \\
\end{array}$ & $\begin{array}{l}\text { Plant Dry } \\
\text { Weight } \\
(\mathrm{kg})\end{array}$ & $\begin{array}{l}100 \text { Seeds } \\
\text { Weight } \\
(\mathrm{g})\end{array}$ & $\begin{array}{l}\text { Panicle } \\
\text { Weight } \\
\text { (g) }\end{array}$ & $\begin{array}{l}\text { Panicle } \\
\text { Length } \\
(\mathrm{cm})\end{array}$ & $\begin{array}{l}\text { Number of } \\
\text { Panicles }\end{array}$ \\
\hline \multirow{3}{*}{ Titron } & $\mathrm{P}+$ & $188.85 \mathrm{a}$ & $12.60 \mathrm{abc}$ & $12.05 \mathrm{ab}$ & $131.97 \mathrm{de}$ & $0.582 \mathrm{abc}$ & $0.435 \mathrm{abc}$ & $3.00 \mathrm{bcd}$ & $25.90 \mathrm{a}$ & $24.25 \mathrm{a}$ & $53.50 \mathrm{abc}$ \\
\hline & P- & $182.15 \mathrm{a}$ & $10.70 \mathrm{~d}$ & $10.60 \mathrm{de}$ & $123.13 \mathrm{f}$ & $0.625 \mathrm{abc}$ & $0.332 b$ & $2.75 \mathrm{~cd}$ & $19.72 \mathrm{~cd}$ & $19.75 \mathrm{bcd}$ & $51.00 \mathrm{bc}$ \\
\hline & mean & 185.5 & 11.65 & 11.32 & 127.55 & 0.60 & 0.38 & 2.87 & 22.81 & 22.00 & 52.25 \\
\hline \multirow{3}{*}{ Butana } & $\mathrm{P}+$ & $141.75 \mathrm{~b}$ & $11.65 \mathrm{bc}$ & $12.60 \mathrm{a}$ & $131.88 \mathrm{~d}$ & $0.45 \mathrm{~d}$ & $0.56 \mathrm{a}$ & $3.75 \mathrm{~cd}$ & $20.52 b$ & $20.62 \mathrm{bcd}$ & $55.50 \mathrm{a}$ \\
\hline & P- & $134.25 \mathrm{~b}$ & $10.65 \mathrm{~d}$ & $11.20 \mathrm{bcd}$ & $125.92 \mathrm{de}$ & $0.27 \mathrm{~d}$ & $0.36 \mathrm{~b}$ & $2.72 \mathrm{~cd}$ & 20.32 & $19.00 \mathrm{~cd}$ & $55.75 \mathrm{ab}$ \\
\hline & mean & 138.00 & 11.15 & 11.9 & 128.9 & 0.60 & 0.46 & 3.23 & 23.93 & 19.18 & 5.62 \\
\hline \multirow{3}{*}{ Arfagadmak } & $\mathrm{P}+$ & $141.13 \mathrm{c}$ & $12.70 \mathrm{ab}$ & $11.95 \mathrm{abc}$ & $145.18 \mathrm{~b}$ & $0.63 \mathrm{ab}$ & $0.31 \mathrm{~b}$ & $3.42 \mathrm{ab}$ & $32.80 \mathrm{abc}$ & $20.25 \mathrm{bcd}$ & $52.25 \mathrm{bc}$ \\
\hline & $\mathrm{P}-$ & $100.20 \mathrm{~d}$ & $10.95 \mathrm{~d}$ & $10.38 \mathrm{e}$ & $140.68 \mathrm{bc}$ & $0.51 \mathrm{abc}$ & $0.42 \mathrm{ab}$ & $2.70 \mathrm{~cd}$ & $19.27 \mathrm{~d}$ & $18.5 \mathrm{~d}$ & $48.50 \mathrm{c}$ \\
\hline & mean & 107.16 & 11.82 & 11.15 & 142.93 & 0.57 & 0.36 & 3.06 & 26.03 & 19.50 & 50.37 \\
\hline \multirow{3}{*}{ Tabat } & $\mathrm{P}+$ & $110.22 \mathrm{~cd}$ & $11.45 \mathrm{dcd}$ & $11.92 \mathrm{abc}$ & $165.13 \mathrm{a}$ & $0.64 \mathrm{ab}$ & $0.35 \mathrm{~b}$ & $3.75 \mathrm{~cd}$ & $25.97 \mathrm{a}$ & 21.37 & $52.25 \mathrm{bc}$ \\
\hline & P- & $100.30 \mathrm{~cd}$ & $11.35 \mathrm{~cd}$ & $11.00 \mathrm{cde}$ & $160.07 \mathrm{a}$ & $0.47 b c$ & $0.35 \mathrm{~b}$ & $2.50 \mathrm{~d}$ & $19.37 \mathrm{~d}$ & $20.50 \mathrm{~b}$ & $52.00 \mathrm{bc}$ \\
\hline & mean & 105.26 & 11.40 & 11.46 & 162.60 & 0.55 & 0.35 & 3.12 & 22.6 & 20.93 & 52.12 \\
\hline \multirow{3}{*}{ Wad Ahmed } & $\mathrm{P}+$ & $103.35 \mathrm{~cd}$ & $13.32 \mathrm{a}$ & $11.45 \mathrm{bcd}$ & $136.72 \mathrm{~cd}$ & $0.67 \mathrm{a}$ & $0.38 \mathrm{ab}$ & $3.57 \mathrm{ab}$ & $24.32 \mathrm{ab}$ & $21.67 \mathrm{~b}$ & $54.50 \mathrm{abc}$ \\
\hline & P- & $99.97 \mathrm{~d}$ & $12.45 \mathrm{afc}$ & $10.26 \mathrm{e}$ & $130.30 \mathrm{c}$ & $0.47 b c$ & $0.37 \mathrm{~b}$ & $3.15 \mathrm{abcd}$ & $17.77 \mathrm{~d}$ & $18.62 \mathrm{~d}$ & $49.75 \mathrm{bc}$ \\
\hline & mean & 101.66 & 12.88 & 10.85 & 133.51 & 0.57 & 0.37 & 3.36 & 21.04 & 20.14 & 52.12 \\
\hline
\end{tabular}

Means followed by the same letter for each parameter were not significant of $5 \%$ level (LSD) 


\subsubsection{Stem Diameter $(\mathrm{cm})$}

Statistical analysis revealed high significant differences between phosphorus treatment and among the five genotypes of sorghum (Table 2). However the interaction between phosphorus and the five genotypes of sorghum was not significant. The highest stem diameter was attained in plant which treated with phosphorus $(13.00 \mathrm{~cm})$ while the lowest was attained in plants without phosphorus (11.22) (Table 3). As shown in (Table 5) Butana gave significantly highest stem diameter (11.900 $\mathrm{cm})$ than the other four varieties. The interaction between phosphorus and the five genotypes of sorghum revealed that Butana with phosphorus had the highest significant stem diameter $(12.60 \mathrm{~cm})$ in comparison with the others, while Wadahmed without phosphorus had the lowest significant stem diameter $(10.263 \mathrm{~cm})$ as shown in Table (5).

\subsubsection{Leaf Area $\left(\mathrm{cm}^{2}\right)$}

The significant differences were shown between phosphorus treatment and high significant differences among the five genotypes of sorghum (Table 2). Also the interaction between phosphorus and the five genotypes of sorghum was not significant. The highest leaf area was attained in plant which treated with phosphorus $\left(142.17 \mathrm{~cm}^{2}\right)$ while the lowest was obtained without phosphorus $\left(136.02 \mathrm{~cm}^{2}\right)$ (Table 3). As shown in (Table 4) Tabat gave significantly the higher leaf area $\left(162.60 \mathrm{~cm}^{2}\right)$ than the other four varieties. The interaction between phosphorus and the five genotypes of sorghum revealed that Tabat with phosphorus and without phosphorus had the highest significant leaf area $\left(165.13 \mathrm{~cm}^{2}\right),(160.07)$ respectively compared to the other genotypes. While Tiron without phosphorus had lowest leaf area $\left(123.13 \mathrm{~cm}^{2}\right)$ as shown in Table (5).

\subsubsection{Plant Fresh Weight (g)}

Statistical analysis exposed significant differences between phosphorus treatment throughout the five genotypes of sorghum- and the interaction between phosphorus and the five genotypes of sorghum (Table 2). The highest weight was reached in plant which treated with phosphorus $(0.5975 \mathrm{~g})$ while the lowest was reached in plant without phosphorus $(0.4735 \mathrm{~g})$ (Table 3$)$. As shown in (Table 4) Titron gave the highest significant weight $(0.6036 \mathrm{~g})$ among the other four varieties. The interaction between phosphorus and the five genotypes of sorghum revealed that Wadahmed with phosphorus had the highest significant weight $(0.6750 \mathrm{~g})$ among the varieties. While Butana without phosphorus had significantly lowest weight $(0.750 \mathrm{~g})$ as shown in Table (5).

\subsubsection{Plant Dry Weight (g)}

There are no significant differences shown in phosphorus treatment, among the five genotypes of sorghum and in the interaction between phosphorus and the five genotypes of sorghum (Table 2). The highest dry weight was attained in plant which treated with phosphorus $(0.4095 \mathrm{~g})$ while the lowest was attained in plant treated without phosphorus $(0.3680 \mathrm{~g})$ (Table3).As shown in (Table 4)

Butana gave significantly highest dry weight $(0.5612 \mathrm{~g})$ than the other four varieties. The interaction between phosphorus and the five genotypes of sorghum revealed that Butana with phosphorus had the highest significant weight $(0.5625 \mathrm{~g})$ among all other genotypes. While Titron treated with phosphorus had significantly the highest weight $(0.4350 \mathrm{~g})$, and lowest weight without phosphorus $(0.3325 \mathrm{~g})$ as shown in Table (5).

\subsection{Grain Yield Characters}

\subsubsection{Length of Panicle $(\mathrm{cm})$}

Statistical analysis showed significant differences in phosphorus treatments but there were high significant differences (0.01) among the five genotypes. However, the interaction between phosphorus and the five genotypes of sorghum was not significant. The taller panicle was attained in plant treated with phosphorus $(21.635 \mathrm{~cm})$ while the shortest was without phosphorus $(19.325 \mathrm{~cm})$ (Table 3). As shown in (Table 4) Titron gave significantly taller panicle $(22.000 \mathrm{~cm})$ than the other four varieties. The interaction between phosphorus and the five genotypes of sorghum revealed that Titron with phosphorus had a significantly taller panicle $(24.250 \mathrm{~cm})$ than the other genotypes. While Wadahmed without phosphorus had significantly the lowest panicle $(18.625 \mathrm{~cm})$ as shown in Table (5).

\subsubsection{Weight of Seeds/Panicle (g)}

In these particular results, high significant differences were seen in phosphorus treatment but there were no significant differences among the five genotypes of sorghum or the interaction between phosphorus and the five genotypes of sorghum (Table 2). The higher weight was attained in plant which treated with phosphorus $(25.505 \mathrm{~g})$ while the lower was obtained in plants without phosphorus (19.295g) (Table 3). As shown in (Table 4) Butana gave significantly higher weight $(23.925 \mathrm{~g})$ than the other four varieties. The interaction between phosphorus and the five genotypes of sorghum revealed that Butana with phosphorus had a significant higher weight $(27.525 \mathrm{~g})$ than the other genotypes. While Wadahmed without phosphorus had significantly the lower weight $(17.775 \mathrm{~g})$ as shown in Table (5).

\subsection{Weight of 1000 Seeds (g)}

Statistical analysis revealed high significant differences in phosphorus treatment among the five genotypes of sorghum, but revealed no significance in phosphorus with 
interaction between the five genotypes of sorghum (Table 2). The highest weight was attained in plant which treated with phosphorus $(3.4250 \mathrm{~g})$ while the lowest weight was obtained in plant without phosphorus (2.7650g) (Table 3). As shown in (Table 4) Wadahmed gave significantly higher weight $(3.3625 \mathrm{~g})$ than the other five varieties. The interaction between phosphorus and the five genotypes of sorghum revealed that Btana with phosphorus had a significant highest weight $(3.7500 \mathrm{~g})$ while Tiron treated with phosphorus had the significantly the lowest weight $(3.000 \mathrm{~g})$ as shown in Table (5).

\subsubsection{Number of Panicle/Plant}

Significant differences were shown in phosphorus but there are high significant differences among the five genotypes of sorghum (Table 2). However, the interaction between phosphorus and the five genotypes of sorghum was not significant. The highest number of panicle was attained in plant which treated with phosphorus (51.400) while the lowest were obtained without phosphorus (48.500) (Table 3). As shown in (Table 4) Butana gave significantly higher number of panicle in plants (57.625) than the other four varieties. The interaction between phosphorus and the five genotypes of sorghum revealed that Wadahmed with phosphorus had a significantly the highest number of panicle in plants (54.500). While Arfagadamk without phosphorus had the significantly lowest number (49.500) as shown in Table (5).

\subsubsection{Yield t/ha:}

Arafagadamak cultivar give high yield (12.74). While the Tiron, Botana, Tabat recorded (1.70), (10.70), (10.0) respectively and Wadahamed had the lowest (6.90) as shown in table (6).

Table 6. Correlation between Different Parameters of Sorghum

\begin{tabular}{|c|c|c|c|c|c|c|c|c|c|}
\hline Trit & $\begin{array}{c}\text { plant } \\
\text { height } \\
(\mathrm{cm})\end{array}$ & $\begin{array}{c}\text { Number of } \\
\text { leaves }\end{array}$ & $\begin{array}{c}\text { Stem } \\
\text { diameter } \\
(\mathrm{cm})\end{array}$ & $\begin{array}{c}\text { Leaf } \\
\text { Area } \\
(\mathrm{cm} 2)\end{array}$ & $\begin{array}{c}\text { Plant } \\
\text { fresh } \\
\text { weight } \\
(\mathrm{kg})\end{array}$ & $\begin{array}{c}\text { Plant dry } \\
\text { weight } \\
(\mathrm{kg})\end{array}$ & $\begin{array}{c}\text { Weight of } \\
100 \\
\text { seeds }(\mathrm{g})\end{array}$ & $\begin{array}{c}\text { Length of } \\
\text { panicle }\end{array}$ & $\begin{array}{c}\text { Number of } \\
\text { panicle }\end{array}$ \\
\hline $\begin{array}{c}\text { plant height } \\
(\mathrm{cm})\end{array}$ & - & -0.11 & 0.15 & -0.49 & 0.03 & 0.11 & -0.19 & 0.24 & 0.30 \\
\hline $\begin{array}{c}\text { Number of } \\
\text { leaves }\end{array}$ & $0.24 \mathrm{Ns}$ & 0.17 & 0.35 & 0,12 & 0,23 & 0.24 & 0.24 & 0.37 \\
\hline $\begin{array}{c}\text { Stem } \\
\text { diameter } \\
\text { (cm) }\end{array}$ & $0.18 \mathrm{Ns}$ & 0.20 & - & 0.31 & 0.21 & 0.29 & 0.47 & 0.15 & 0.43 \\
\hline $\begin{array}{c}\text { Leaf Area } \\
\text { (cm2) }\end{array}$ & $0.16 \mathrm{Ns}$ & -0.5 & 0.20 & - & 0.14 & 0.05 & 0.20 & 0.14 & 0.40 \\
\hline $\begin{array}{c}\text { Plant fresh } \\
\text { weight (kg) }\end{array}$ & 0.05 & 0.28 & 0.33 & -0.58 & - & 0.28 & 0.33 & 0.15 & 0.16 \\
\hline $\begin{array}{c}\text { Plant dry } \\
\text { weight (kg) }\end{array}$ & 0.31 & -0.10 & 0.15 & 0.05 & 0.15 & - & 0.11 & 0.34 & 0.37 \\
\hline $\begin{array}{c}\text { Weight of } \\
\text { 100 seeds } \\
\text { (g) }\end{array}$ & 0.15 & -0.11 & 0.18 & -0.13 & -0.03 & 0.17 & - & -0.01 & 0.77 \\
\hline $\begin{array}{c}\text { Length of } \\
\text { panicle }\end{array}$ & 0.15 & 0.40 & 0.57 & 0.03 & 0.12 & 0.05 & -0.01 & - & 0.34 \\
\hline $\begin{array}{c}\text { Number of } \\
\text { panicle }\end{array}$ & 0.14 & -0.10 & $-0,49$ & -0.11 & 0.5 & 0.17 & 0.12 & 0.05 & - \\
\hline
\end{tabular}


Phosphorus fertilizer was added to five cultivars of sorghum in order to study the physiological phosphorus use efficiency and its effect on productivity. According to this was the soil analyzed before and after phosphorus fertilizer addition as well as analyzing the percentage of phosphorus in the grains of the five cultivars before and after adding the phosphorus. In soil analysis the percentage of phosphorus in the soil was $17 \%$ and the percentage after sowing using phosphorus fertilizer and without using it is $3 \%$ and $7 \%$ respectively which means that the uptake of phosphorus by the plant from soil increase after adding the fertilizer. Plant height was increased with the addition of phosphorus, because it helped in the process of cells division. This result is not similar to the findings of Gasim (1998), who reported that phosphorus did not affect---- plant height. On the other hand that leaf area was also increased because of phosphorus which affected the photosynthesis significantly. This result was in line with Abusuwar and Mohammad (1997) who stated that the effect of phosphorus on forage productivity of Napier grass was positive. It increased forage fresh and dry weight of Napier grass in the first and the ratoon crop. The increment of seed weight was due to the role which the phosphorus plays in composition of carbohydrates, proteins and seeds. This result agreed with Charles et.al (2006) stating that yield increase is expected from phosphorus application. Samuel et.al (2012) also stated that grain yield was increased significantly by added Nitrogen and Phosphorus only. The increment of the fresh weight of the plant was resulted from the addition of phosphorus, because its effect on some physiological processes. This result was similar with Mozzamll (2009) writing that phosphorus increased the column density of the crop. Arafagadamak cultivar has the highest yield productivity $(12.74 \mathrm{~T} / \mathrm{ha})$ though its phosphorus uptake was the lowest (19.169 PPM) and this implies that the utilization of phosphorus fertilizer was excellent because of its high physiological efficiency (10.37) compared to the other cultivars. Although Botana had the highest uptake of the fertilizer (40.462 PPM), but its productivity was equal to Titron, but Titron itself had an uptake of (28.735 PPM), with the knowledge that the physiological efficiency of both was almost equal (Botana 8.70, Titron 8.69). Apparently, Titron utilize the fertilizer in the growth characters while Botana utilization was balanced between all yield components and productivity. The uptake. Percentage of Tabat was (27.624 PPM), however its physiological efficiency was low, thus meaning that it utilized the fertilizer in some of the yield growth (leaf area, fresh weight), and other part went to yield components (100 seeds weight). Wadahmed took a high percentage of the fertilizer (30.075 PPM), however it had the lowest productivity and the lowest physiological efficiency, $(9.45$ tan/h productivity) and (6.74 physiological efficiency), thus show that it utilize its fertilizer in yield growth (fresh weight and 100 seeds weight mostly).

\section{REFERENCES}

[1] Abdelrahman, A.H., 1998. Trends in Sudanese Cereal Production, Consumption and Trade. Working Paper 98-WP-198. Amer., Iowa, USA.

[2] Abusuwar, A.O. and G.G. Mohamed, (1997).Effect of nitrogen and phosphorus fertilizers on growth and yield of some graminaceous forges. University of Khartoum Journal of Agricultural Sciences, 2:37-55. RDA, Aleppo, Syria, pp27-30.

[3] Adam, H.S. (2003) the Agricultural CLIAME. Second Edition (in Arabic). Gezira University Press.PP119.

[4] 12- Abdelgadir, M.A.M.(2010).Effect of Nitrogen fertilizer on Irrigated pearl Millet Pennisetum arercanum (L.K-Scham) Forge Yield, M.Sc. Thesis Sudan University of Science and Technology Sudan.PP83

[5] Charls, S. Wortmam, Richard B. Feguson, Gary W. Hegert, Harles Ashapiro and Timm. Revised January 2006.

[6] GIZ, 2014. Climate Change Impact Chain for Sorghum and Millet. GIZ and Federal Ministry for Environment, Nature Conservation and Nuclear Safety, Germany.

[7] Mahgoub, F., 2014. Current Status of Agriculture and Future Challenges in Sudan. NORDISKA Africa Institute, UPPSALA

[8] McLaughlin M J, Fillery I R and Till a R (1991) Operation of the phosphorus, sulphur and nitrogen cycles. In Australia's Renewable Resources: Sustainability and Global Change. Eds. Gifford R M and Barson M. M. pp. 67-116. Bureau of Rural Resources, Canberra, Australia.

[9] Moamll Ahmed, PHD (2009).Forge yield potential of the secondary crop of sorghum bicolor L. Moench, CV Abusabein as influenced by some agronomic practices of the primary crop.

[10] Olsen,S.R, and Cole C. V. (1954).Estimation of available phosphorous in soil by extraction with NaHco3. W.S. Dept. Agriculture No.393.

[11] Reda, F., 2014. Challenges and Opportunities for Strategic Agricultural Commodity Value Chains Development in the IGAD Region. AU/SAFGRAD Report.

[12] Ryan, J.S.G.K. Haunsen and A. Rashid (1996). Soil and plant Analysis Manual Adapted for the west Asia and North Africa Region (WANA).

[13] Samuel, Saaka Jedua, Buah, James M. Kombiok and Luke N. Abatonia (2012). Grain Sorghum Response to NPK fertilizer in the Gaines Savanna of ahona. Taha, M. A. M. The Influence of Innovations Attributes on the Adoption of Sowing Improved Sorghum Varieties in Dulgo Block (Gezira Scheme) - thesis of M.Sc. University of Gezira, (1998).

[14] Sharpley A, Foy B and Withers P (2000). Practical and innovative for the control of agricultural phosphorus losses to measures water: An overview. J. Environ. Quality 29, 19.

[15] Sudan Food Security Outlook. 2013. Minstry of Agriculture.Khartoum. Sudan. 